\title{
BEHAVIOR OF HIGH-STRENGTH CONCRETE CYLINDERS REPAIRED WITH CFRP SHEETS
}

\author{
Mohammad PANJEHPOUR ${ }^{\mathrm{a}}$, Nima FARZADNIA ${ }^{\mathrm{b}}$, Ramazan DEMIRBOGA ${ }^{\mathrm{c}}$, \\ Abang Abdullah Abang ALI ${ }^{\mathrm{b}}$ \\ ${ }^{a}$ Center of Advanced Concrete Technology (CACT), Department of Civil Engineering, Faculty of Science, \\ Engineering, Technology and Mathematics (FOSTEM), INTI International University, 71800 Nilai, Malaysia \\ ${ }^{b}$ Housing Research Center, Faculty of Engineering, Universiti Putra Malaysia, 43400 Serdang, \\ Selangor, Malaysia \\ ${ }^{c}$ Civil Engineering Department, Engineering Faculty, Ataturk University, 25240 Erzumum, Turkey
}

Received 25 Apr 2012; accepted 04 Mar 2013

\begin{abstract}
This study aims to investigate the behavior of damaged high-strength concrete cylinders repaired using carbon fiber reinforced polymer (CFRP) sheet. The experimental work on CFRP-wrapped concrete cylinders with various predamage levels indicated that CFRP can precisely resist the axial aggravated deformation of cylinders caused by damaging under uniaxial loading. The findings also revealed that the energy absorption of the damaged specimens confined with CFRP was restored approximately three times more than that of the undamaged specimens without confinement. Therefore, an empirical relationship exists between the pre-damage levels and the uniaxial compressive strength reduction of the concrete cylinders.
\end{abstract}

Keywords: FRP, concrete, confinement, damage, repair.

\section{Introduction}

Since the last decade, interest of researchers in repairing, strengthening, and retrofitting of existing structures with fiber reinforced polymer (FRP) has been increasing (Colalillo, Sheikh 2011; Ferrier et al. 2011; Hag-Elsafi et al. 2004; Maalej, Leong 2005; Matthys, Taerwe 2006; Panjehpour et al. 2011; Taillade et al. 2011). Several studies have proven the economical and environmental benefits of the application of FRP in constructions (Cromwell et al. 2011; Moy 2001; Sasher 2008). Rehabilitation and repair of concrete structures in light of the degradation of structure members because of aging, increase of structure load capacity, and construction design errors is increasingly needed (Pan, Leung 2007). FRP wrapping is one of the methods for increasing the axial strength, shear strength, and seismic resistance of concrete members.

The column is one of the most critical parts of a structure that is usually loaded axially (Manal K 2011). Numerous studies have focused on the retrofitting and strengthening of concrete columns using FRP sheet with respect to FRP confinement performance (Csuka, Kollár 2011; Gu et al. 2012; Jiang, Teng 2012; Naderian et al. 2011; Promis, Ferrier 2012). The application of FRP sheets to columns can be classified into three types of wrapping: partial wrapping in the form of continuous spi- ral straps, partial wrapping in the form of discrete ring straps, and full wrapping (Teng 2002). FRP sheets are wrapped around the column in the circumferential direction parallel to their fiber orientation. The axial strength of the concrete column increases with the triaxial stress condition created by FRP confinement (Lam et al. 2006). Moreover, FRP wrapping also prevents the premature spalling failure of the column, particularly for lateral loading that may occur during earthquake (Giuseppe 2006; Lam et al. 2006; Sasmal et al. 2011).

Previous studies have focused on the issues of ductility and stress-strain curve of FRP-confined concrete cylinders. The present study discusses the preceding issues on pre-damaged concrete cylinders confined with CFRP sheets. The ductility of concrete members such as columns usually decreases because of the unstrengthening caused by damage (FIB 2001). Lateral confinement of the concrete column in the compressive zone is one of the alternative techniques for enhancing the ductile behavior of a column by preventing pre-mature cracking and crushing (Gdoutos et al. 2000). The effect of FRP confinement on the ductility of undamaged concrete columns in the compressive zone has been investigated by a number of researchers (Hadi 2007; Jiang, Teng 2007).

Typical stress-strain curves for undamaged FRPconfined concrete cylinders have been proposed by re-

Corresponding author: Mohammad Panjehpour

E-mail: mohammad.panjehpour@newinti.edu.my 
searchers with respect to FRP properties, such as the number of layers and thickness of FRP (FIB 2006; IAEE 1992; Teng 2002). In addition, numerical stress-strain models of FRP-confined concrete cylinders have been recommended (Wei, Wu 2012).

The behavior of damaged concrete members repaired with FRP is highly influenced by sound concrete substrate and proper surface preparation (Lam, Teng 2002). However, the different types and sizes of defects for the damaged concrete members are still undefined in the standards. Moreover, the threshold of critical defects has not yet been sufficiently studied (Lam et al. 2011; Panjehpour et al. 2011). According to previous studies, far too little attention has been given to the effectiveness of CFRP confinement for different levels of damage on concrete columns.

The present study aims to investigate the behavior of damaged high-strength concrete cylinders repaired using CFRP sheet. This study is the first research to date that focuses on the effect of damage level on the compressive strength and energy absorption of repaired specimens using one layer of CFRP sheet. In addition, the stress-strain curves and energy absorption of all concrete cylinders comprising unconfined and CFRP-confined control specimens, as well as CFRP-confined pre-damaged specimens, are also compared. The CFRP-confined concrete cylinders with $40 \%, 55 \%, 70 \%, 85 \%$, and $100 \%$ pre-damage are tested under uniaxial compressive load to evaluate the efficiency of CFRP confinement in damage status. Moreover, the concrete cylinders with $100 \%$ predamage, considered as defected specimens, are discussed in separate section in this paper.

\section{Experimental program}

The experimental program aims to evaluate the effectiveness of FRP confinement for repairing various predamage levels of high-strength cylindrical concrete specimens. The experimental specimens were categorized into two groups according to the damage level: cracked specimens and defected specimens. The specimens were tested under four different conditions:

1) Three undamaged specimens without any CFRP wrapping as unconfined control specimens;

2) Three undamaged specimens with CFRP full wrapping as confined control specimens;

3) Twelve specimens comprising four groups with $40 \%, 55 \%, 70 \%$, and $85 \%$ pre-damage;

4) Three defected specimens with $100 \%$ pre-damage.

\subsection{Material properties}

Type I Portland cement, natural sand, gravel, and water were used to form the concrete cylinders according to ASTM C39 (2014). Crushed quartz, with the maximum aggregate size of $12.5 \mathrm{~mm}$ and bulk specific gravity of 2.46, were utilized in this batch. Single batch of high-strength concrete was prepared to fabricate 21 cylindrical samples.
In this experiment, $10 \%$ silica fume and a $\mathrm{w} / \mathrm{b}$ ratio of 0.35 were chosen to achieve high-strength concrete.

One layer of unidirectional CFRP, with areal weight of $200 \mathrm{~g} / \mathrm{m}^{2}$ and thickness of $0.111 \mathrm{~mm} / \mathrm{ply}$, and two-part epoxy impregnation resin were utilized for full wrapping of the specimens by wet lay-up system. The typical properties of the CFRP sheet and epoxy resin provided by the manufacturer are illustrated in Table 1. Both CFRP sheet and epoxy resin, with product data sheets of sikadur-330 and sikaWrap-230, respectively, were obtained from Sika Company.

\subsection{Casting and curing of specimens}

The concrete specimens were demolded at 24 hours after casting, and cured in saturated lime water for 28 days. Afterward, the specimens were allowed to air-dry for the next 28 days in an outdoor environment to resemble the real situation before being damaged at different levels.

\subsection{Pre-damaging of specimen}

Figure 1 shows the uniaxial compressive tests conducted on the specimens using universal testing machine, which provides stress and displacement as electrical output data. According to the ASTM C39 (2014), cylindrical specimens with the size of $150 \times 300 \mathrm{~mm}$ were loaded to determine the ultimate uniaxial compressive strength of unconfined specimens, which was $65.8 \mathrm{Mpa}$. The other specimens were loaded until they reached $40 \%, 55 \%$,

Table 1. Typical properties of CFRP sheets and epoxy

\begin{tabular}{lcccc}
\hline Materials & $\begin{array}{c}\text { Tensile } \\
\text { strength } \\
(\mathrm{Mpa})\end{array}$ & $\begin{array}{c}\text { Tensile } \\
\text { modulus of } \\
\text { elasticity } \\
(\mathrm{Gpa})\end{array}$ & $\begin{array}{c}\text { Elongation } \\
\text { at break }\end{array}$ & $\begin{array}{c}\text { Bond } \\
\text { strength } \\
(\mathrm{Mpa})\end{array}$ \\
\hline $\begin{array}{l}\text { CFRP } \\
\text { sheet }\end{array}$ & 3900 & 230 & $\begin{array}{c}1.5 \% \\
(7 \text { days at } \\
\left.+23^{\circ} \mathrm{C}\right)\end{array}$ & - \\
\hline $\begin{array}{l}\text { Epoxy } \\
\text { resin }\end{array}$ & 30 & 4.5 & $\begin{array}{c}0.9 \% \\
(7 \text { days at } \\
\left.+23^{\circ} \mathrm{C}\right)\end{array}$ & $>4$ \\
\hline
\end{tabular}

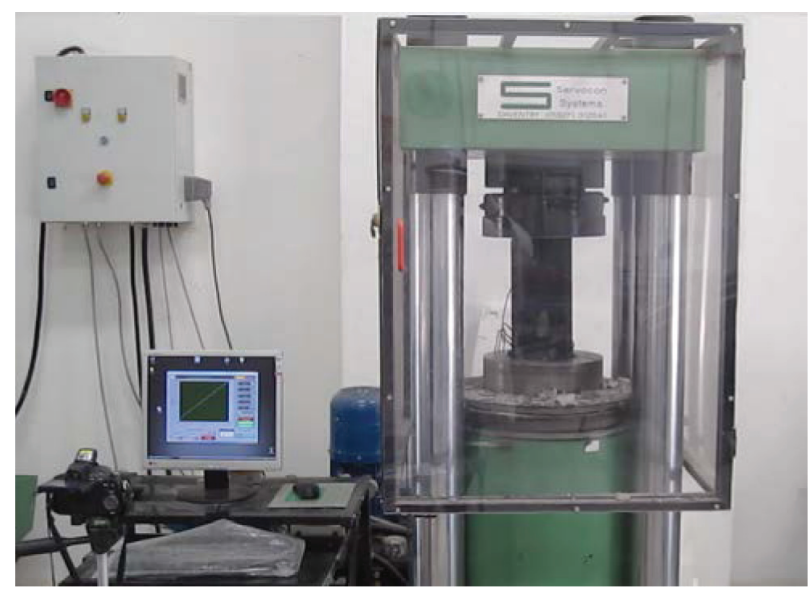

Fig. 1. Test set up 
$70 \%, 85 \%$, and $100 \%$ of ultimate uniaxial compressive strength to compress to different pre-damage levels. A portable microscope with a resolution of $0.02 \mathrm{~mm}$ was used to measure the crack width.

\subsection{Repairing of damaged specimens}

Excluding three specimens used as unconfined control specimens, the other pre-damaged specimens were fully wrapped with one layer of CFRP sheets. The surface of concrete specimens was rubbed with sand paper to prevent the debonding or delamination of CFRP sheets. In addition, the dusts and particles inside the wide cracks were removed by air compressor. Figure 2 illustrates the specimens with $100 \%$ pre-damage, which are considered as defected specimens. The repairing method utilized for these specimens varies from the other pre-damaged specimens. The core of the concrete was observed to be still undamaged for $100 \%$ pre-damaged specimens. Hence, only their surface with small parts of defect was needed to be filled and re-shaped using grout, with respect to ASTM C 476-02 (2009) and BS EN 1504 (CS 2009) before CFRP confining. The defected specimens were then remolded, as illustrated in Figure 3. The grout was poured inside the mould on the vibration table. This part of repairing is the only different part of defected specimens repairing process from the other damaged specimens. The wet lay-up system was utilized to wrap the specimens, and $150 \mathrm{~mm}$ overlapping of CFRP sheet was used in the hoop direction.

The hardener and resin (1:4) were mixed for three minutes to prepare the two-part epoxy impregnation resin based on the recommendation of the manufacturer. The hardener and resin were mixed with a spindle attached to a slow-speed electric drill with a maximum rate of $600 \mathrm{rpm}$ until the material became smooth in uniform grey color. Both the pot life and the open time were approximately 30 minutes. Considering the average outdoor environment temperature and curing details provided by the manufacturer of the epoxy resin, all of the CFRPconfined specimens were cured for two days to ensure CFRP-concrete interface bonding. Finally, the whole specimens were tested under uniaxial compressive load to reach their failure load. The average of the results, including stress and strain, was used to draw the curve based on the three specimens for each damage level to

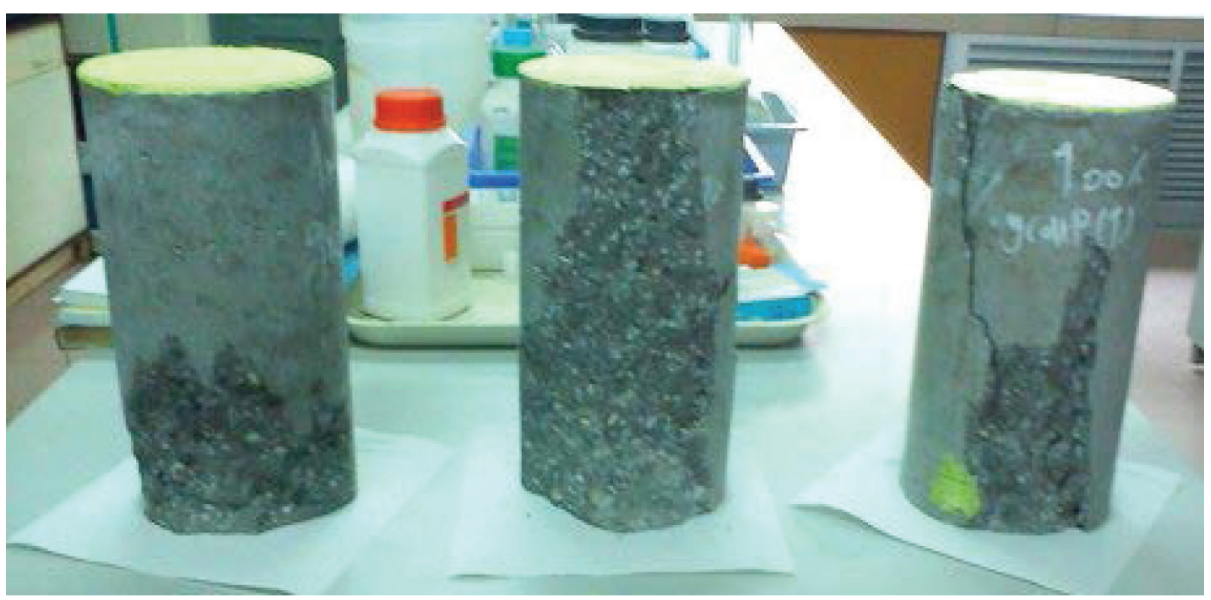

Fig. 2. Defected specimens with level of $100 \%$ pre-damage



(a)

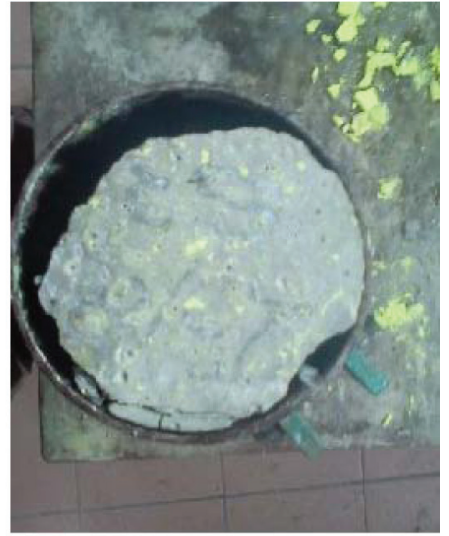

(b)

Fig. 3. Defected specimen (a); remolding of defected specimen (b) 


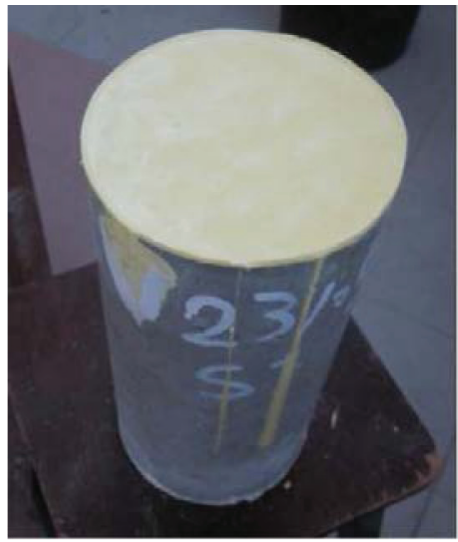

(a)

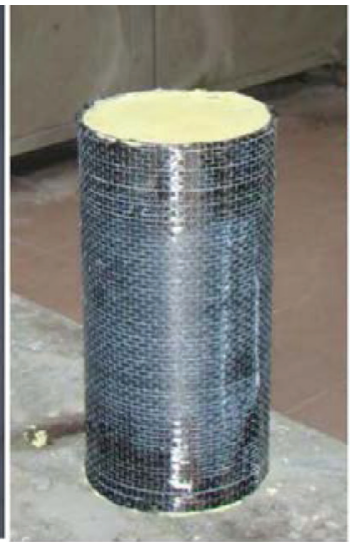

(b)

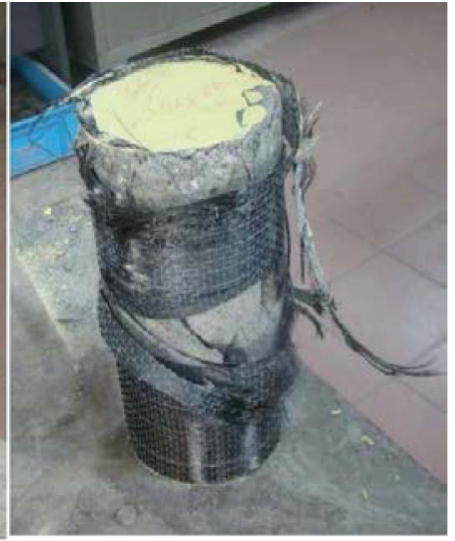

(c)

Fig. 4. Unconfined specimen (a); Confined specimen before compressive strength test (b); Confined specimen after compressive strength test (c)

achieve an accurate stress-strain curve. Figure 4 shows the unconfined specimen and CFRP-confined specimens before and after the compressive test.

\section{Experimental results and discussions}

\subsection{Test observations and failure mode}

Failures of FRP-wrapped cylindrical concretes occurred with FRP rupture and compressive concrete crushing, as predicted in previous studies (ilki et al. 2009). This failure was due to the concrete crumbling and cracking under confinement pressure caused by FRP wrapping.

\subsection{Defected specimens}

Defected specimens that are $100 \%$ pre-damaged in this study can reach up to $68.90 \%$ of the compressive strength of the unconfined control specimen after only reshaping with grout based on ASTM C 476-02 (2009) and BS EN 1504 (CS 2009). Using CFRP confinement after reshaping with grout enhanced the compressive strength of the defected concrete cylinders to approximately $84.90 \%$ of the compressive strength of the unconfined control specimens. Hence, the effect of one layer of CFRP on the compressive strength of defected specimens after reshaping with grout was approximately $23.22 \%$. This enhancement is approximately $5 \%$ lower than the enhancement for control specimens confined with CFRP sheet. The compressive strengths of the unconfined control specimens, defected specimens reshaped with grout, and CFRP-confined defected specimens reshaped with grout are shown in Table 2.

The peak strain of the ultimate compressive strength increased from 0.0090 for CFRP-confined control specimen to 0.0099 ( $10 \%$ increase) for CFRP-confined defected specimen. This increase is due to the defect that causes more ductility than the undamaged specimen. Past studies have recorded that, the axial strain of CFRPconfined cylindrical specimens without any pre-damage related to ultimate compressive stress $\left(\varepsilon_{c c}\right)$ varies from
Table 2. Compressive strength of control and repaired specimens

\begin{tabular}{lc}
\hline Specimens status & $\begin{array}{c}\text { Uniaxial compressive } \\
\text { strength (Mpa) }\end{array}$ \\
\hline Unconfined control specimen & 65.80 \\
\hline $\begin{array}{l}\text { Defected specimen reshaped } \\
\text { with grout }\end{array}$ & 45.34 \\
\hline $\begin{array}{l}\text { CFRP confined defected } \\
\text { specimens after reshaping with } \\
\text { grout }\end{array}$ & 55.87 \\
\hline
\end{tabular}

$0.106 \%$ to $2.516 \%$ (Jiang, Teng 2007; Lam, Teng 2002), $0.900 \%$ to $2.080 \%$ (Jiang, Teng 2007; Lam et al. 2006), and $0.691 \%$ to $3.700 \%$ (Jiang, Teng 2007; Teng et al. 2007). In addition, the efficiency of FRP confinement with respect to several relevant models proposed by researchers has been analyzed to find proper equation for estimating the compressive strength of FRP-confined concrete cylindrical specimens (Realfonzo, Napoli 2011). In the present study, the $\varepsilon_{c c}$ for the defected specimen repaired with CFRP after reshaping with grout is $0.895 \%$. The difference in the $\varepsilon_{c c}$ obtained by different studies are influenced by some parameters such as type of fiber, including carbon and glass, compressive strength of concrete $\left(\mathrm{f}^{\prime}{ }_{c o}\right)$, thickness of FRP $(\mathrm{t})$, modulus of elasticity of FRP $\left(\mathrm{E}_{F R P}\right)$, and type of epoxy.

\subsection{Specimens with $40 \%$ to $85 \%$ pre-damage}

Typically, cracks wider than $0.3 \mathrm{~mm}$ in concrete members require sealing to prevent the entry of moisture, oxygen, and other materials, in contrast to the cracks narrower than $0.3 \mathrm{~mm}$, which are considered as superficial cracks (Gambhir 2010; Komorowski 2011). Thus, the cracks wider than $0.3 \mathrm{~mm}$ are injected with epoxy before wrapping with CFRP sheet in this experiment. The widths of the cracks for the current specimens with $40 \%$ pre-damage were not wider than $0.3 \mathrm{~mm}$. Figure 5 illustrates the compressive strength reduction for different pre-damage 


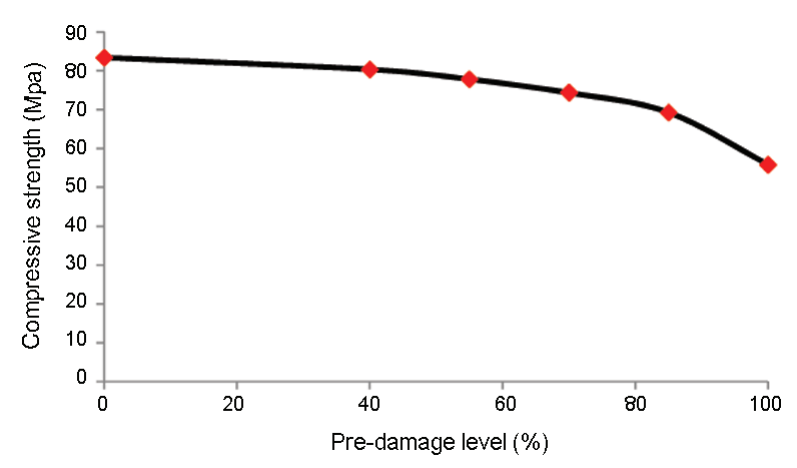

Fig. 5. Uniaxial compressive strength of CFRP-confined pre-damaged specimens

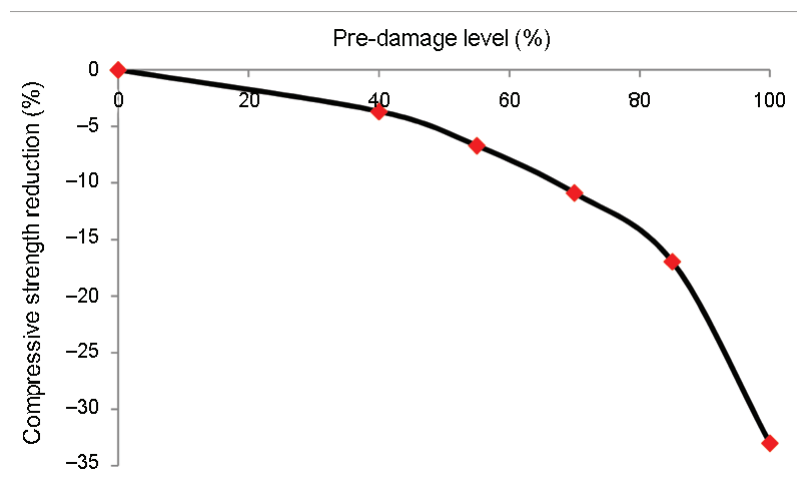

Fig. 6. Compressive strength reduction of pre-damaged specimens confined with CFRP

levels of CFRP-confined pre-damaged specimens. Subsequently, an empirical relationship between the predamage levels and reduction of compressive strength of CFRP-confined pre-damaged specimens is indicated in Figure 6. The compressive strength of CFRP control specimens was considered as the reference value to calculate the total compressive strength reduction in this study.

According to the experimental results, a slight compressive strength reduction of about $3.67 \%$ occurred in the $40 \%$ pre-damaged specimen. This result indicates the significant efficiency of CFRP confinement up to $40 \%$ pre-damage because CFRP can enhance the strength of specimen very close to the control specimen, with only approximately $3.67 \%$ reduction. The width of the cracks for $55 \%$ pre-damage was slightly wider than $0.3 \mathrm{~mm}$ in some parts of the concrete specimens. The reduction of compressive strength from $40 \%$ to $55 \%$ pre-damage was around $3.15 \%$, which may be due to the wider cracks. However, the total reduction of compressive strength in $55 \%$ pre-damage specimen was approximately $6.70 \%$. The cracks on $70 \%$ pre-damaged specimens became wider than the previous specimens. In some parts of the top and bottom of cylindrical specimens, small pieces of concrete were delaminated, with maximum dimension of approximately $10 \mathrm{~mm}$. In this level of pre-damage, crushing of concrete was not observed.
Lastly, the specimens were loaded up to $85 \%$ predamage. The cracks became wider than the previous specimens, and some parts of the concrete were delaminated. Crushing of the concrete occurred at the top and the bottom regions of the specimens; however, defected parts of concrete on the specimen bodies were not observed. The reduction of compressive strength from $70 \%$ to $85 \%$ pre-damage was approximately $6.81 \%$, greater than the previous specimens. This reduction was due to the high pre-damage level that caused wide cracks and small parts of defect. The total compressive strength reduction of CFRP-confined specimens with $85 \%$ predamage was $16.96 \%$. This result indicates the efficiency of CFRP confinement, which can compensate the reduction effect of damage upon the compressive strength of cylindrical specimens. CFRP sheet is dormant until the ultimate strength of the corresponding unconfined predamaged specimens is reached. This is because of higher transverse Poisson's ratio and lower axial stiffness of FRP than those of concrete.

Figures 5 and 6 illustrate the comparisons of the uniaxial compressive strength of the defected specimens with the other specimens. Crucially, defected specimens were reshaped with simple grout before confining with CFRP. The compressive strength reduction of CFRPconfined defected specimens was approximately $19.32 \%$ more than those of the $85 \%$ pre-damaged specimens. Hence, CFRP-confined defected specimens can reach up to about $84.90 \%$ of the strength of unconfined control specimens.

\subsection{Relationship between pre-damage levels and compressive strength reduction}

Types of concrete column damages that comprise cracking, crushing, and defecting can be roughly determined by observation. Figure 7 illustrates an empirical relationship between pre-damage levels and uniaxial compressive strength reduction of high-strength concrete cylindrical specimens. This relationship was derived from the experimental results within the scope of the present research. In future studies, this relationship can

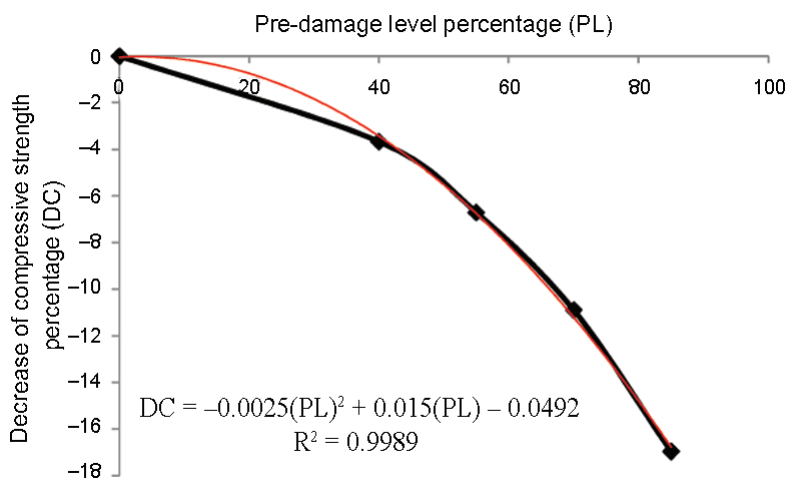

Fig. 7. Relationship between pre-damage level and decrease of compressive strength 
be further calibrated with considering grade of concrete, number of the layers, thickness, and modulus of elasticity of CFRP. Nevertheless, the relationship reveals a schematic diagram to clarify how the reduction of uniaxial compressive strength of concrete cylinders varies with the damage levels. According to this relationship, similar to the parabolic curve, the uniaxial compressive strength reduction for CFRP-confined cylindrical specimens can be predicted based on the pre-damage level. Thus, the uniaxial compressive strength reduction of the CFRP-confined cylindrical specimen pertinent to $50 \%$ pre-damage may be about $5.54 \%$.

\subsection{Ductility}

The ductility of concrete members such as column decreases because of the unstrengthening caused by damage (FIB 2001). Lateral confinement of the concrete column in the compressive zone is one of the alternative techniques that can be utilized to enhance the ductility of a column (Gdoutos et al. 2000). The area under the load-deformation curve for all specimens comprising the unconfined and CFRP-confined control specimens, as well as the CFRP-confined pre-damaged and defected specimens, was calculated using Simpson's rule. The amount of this area represents the energy absorption of the specimens, as illustrated in Figure 8. Numerous studies have shown a consistent positive correlation between energy absorption and ductility of concrete cylinders. Crucially, the initial small part of the stress-strain curve is likely to represent initial settlements of the specimen within the testing rig. However, the effect of this part of curves upon the accuracy of calculation for the area under load-axial deflection curves is not the major concern of this study.

The experimental results indicated that a significant increase in the energy absorption of CFRP-confined control specimens occurred compared with the unconfined control specimens. The energy absorptions of the confined and unconfined control specimens, as well as the confined defected specimens, are illustrated in Figure 8. CFRP confinement increases the energy absorption of the undamaged specimen by approximately more than

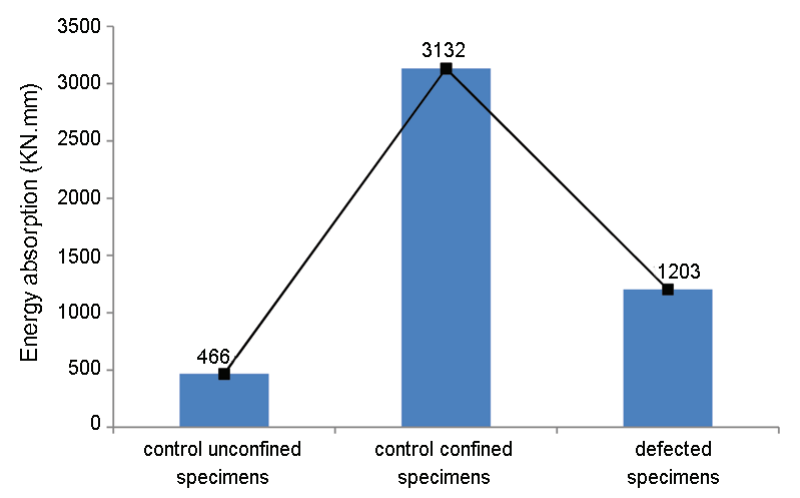

Fig. 8. Energy absorption of specimens six times. Based on the experimental results, the energy absorption of the CFRP-confined specimens with $40 \%$ pre-damage is 1.5 times more than those of the defected specimens, with $100 \%$ pre-damage, because the damaged concrete specimens were weaker than the undamaged concrete specimens in absorbing the energy. From another point of view, debonding may be induced by major cracks of the concrete (Pan, Leung 2007). The increase of interfacial bonding stress between the concrete and FRP can enhance the strength and stiffness of the repaired columns (Guoqiang 2006; Li et al. 2003). For the repairing of damaged concrete specimens, the FRP is wrapped on the surface of the cracked concrete cylinders that are not as smooth as undamaged concrete cylinders. Thus, only a part of axial load can be transferred to the FRP sheet through interfacial bonding and interfacial friction force. As a result, the degradation of energy absorption from CFRP-confined specimen with $40 \%$ pre-damage to the defected specimens may be due to the weakened concrete and debonding of the CFRPconcrete interface. Nevertheless, bonding stress may affect the stiffness and may have minor effect on the compressive strength because the bond does not reduce the ultimate confinement pressure.

Experimental results indicated that CFRP confinement increases energy absorption by approximately three times for specimens with $40 \%$ to $85 \%$ pre-damage, as well as defected specimens, compared with the unconfined control specimens. This result implies the effectiveness of CFRP confinement for energy absorption of the repaired concrete cylinders, as proven for undamaged concrete columns in previous studies (Hadi 2007; Jiang, Teng 2007).

\subsection{Stress-strain curve}

In the present study, the behavior of all specimens was observed throughout the load history until the occurrence of FRP material rupture. The stress-strain curve is characterized by two distinct regions for CFRP-confined control specimens. The first region is approximately linear where the CFRP wrapping is dormant, whereas the second region after some fluctuation in the beginning is approximately linear with the lower gradient compared with the first region. The preceding typical stress-strain curve has been proposed by several researchers for undamaged FRP-confined specimens with respect to the FRP properties such as number of layers and thickness of FRP (FIB 2006; Teng 2002). In addition, some researchers also recommend the numerical stress-strain model of concrete for FRP-confined columns (Wei, Wu 2012).

Figure 9 illustrates the stress-strain curves of all specimens comprising confined and unconfined control specimens, as well as confined pre-damaged specimens. These curves are drawn based on the average strain measured using machine displacements, as shown in Figure 1. The former regions of stress-strain curves for all specimens are almost similar, as indicated by the dashed line in Figure 9. The stress-strain curves of the 


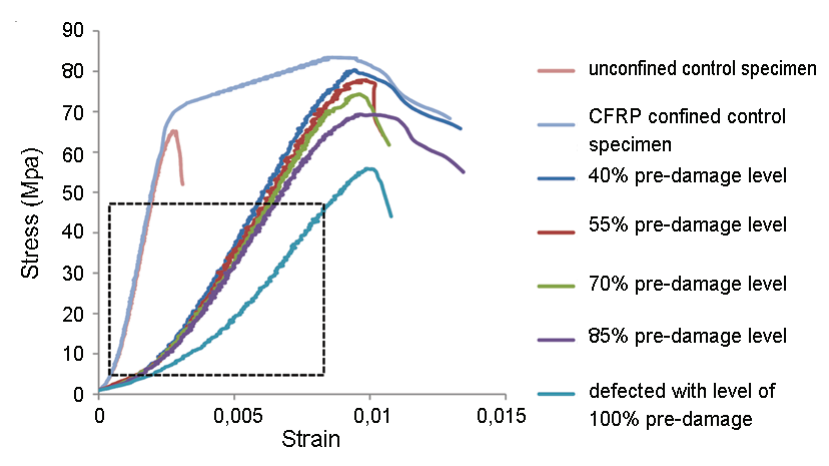

Fig. 9. Stress-strain curve of all specimens

concrete cylinders varied from linear to parabolic from undamaged status to higher damage level. Moreover, the concavities of curves increased from lower to higher pre-damage level, which may be due to increasing void content caused by cracking and crushing. Consequently, the softening of the concrete occurred. The increase of concavity implies that the brittleness index decreases as pre-damage level increases.

\section{Conclusions}

This study addresses the repair of high-strength concrete cylinders with CFRP sheet at various pre-damage levels. The uniaxial compressive stress, stress-strain curves, and energy absorption of the pre-damaged concrete cylinders confined with CFRP sheets are compared with CFRPconfined and unconfined specimens without any damage as control specimens. According to the experimental investigation, the following conclusions can be drawn:

1. CFRP confinement can compensate the reduction effect of damage on the compressive strength of the concrete cylindrical specimens. The strength reduction of CFRP-confined concrete cylinders with $85 \%$ pre-damage was only about $16.96 \%$, with CFRPconfined control specimen as reference value.

2. Using CFRP confinement after reshaping the concrete cylinders with grout enhances the compressive strength of the defected high-strength concrete cylinders to approximately $84.90 \%$ of the compressive strength of unconfined control specimens.

3. An empirical relationship between pre-damage levels and uniaxial compressive strength reduction for concrete cylinders was established in this study. This relationship is approximately similar to a parabolic curve, which roughly shows how uniaxial compressive strength of concrete cylinders reduces with the increase of damage level.

4. Comparing unconfined and CFRP-confined control specimens, the energy absorption increased more than six times using CFRP confinement.

5. CFRP confinement increases the energy absorption for different damage levels of specimens by approximately three times compared with the unconfined control specimens. This result indicates the effec- tiveness of CFRP confinement for energy absorption of the repaired concrete cylinders.

6. A degradation of energy absorption of the CFRPconfined pre-damaged concrete cylinders was observed from $42.20 \%$ to $61.59 \%$, respectively, for $40 \%$ to $100 \%$ pre-damage, considering CFRPconfined control specimen as the reference. The degradation may be due to the weaker concrete and lower interfacial bonding stress between the concrete and CFRP caused by cracking at low damage level, crushing at high damage level, and defecting for $100 \%$ damage.

7. The stress-strain curves of the concrete cylinders from undamaged status to higher damage level vary from linear to parabolic. In addition, the concavities of the curves increased from lower to higher pre-damage level, which may be due to the increase of void content caused by cracking and crushing. Consequently, softening of the concrete occurred.

8. As implied by the stress-strain curves, utilizing CFRP sheets has slight effect upon the linear part of the stress-strain curves for the confined control specimens. CFRP is dormant in preceding part; however, its effects are considerable in softening plastic region ensuing.

9. CFRP sheet is dormant until the ultimate strength of the corresponding unconfined pre-damaged specimens is reached. This is because of higher transverse Poisson's ratio and lower axial stiffness of CFRP than those of concrete.

In conclusion, CFRP, which resists the axial aggravated deformation due to the damage of concrete cylinders under uniaxial loading, is effective in providing confinement for high-strength concrete cylinders with different damage levels. However, this research can be further explored by considering size effect, different concrete compressive strengths, and FRP properties. In addition, it would be more comprehensive to investigate the relation of Poison's ratio of CFRP repaired concrete cylinders to Poisson's ratio and stiffness of CFRP.

\section{Acknowledgements}

The authors appreciate Housing Research Centre for providing financial support and the requirements for this research. The corresponding author would like to extend his gratitude to Taw Ly Wen, the English Instructor from UPM for her comments. The corresponding author would also like to thank Center of Advanced Concrete Technology (CACT) for providing scientific support for this research.

\section{References}

ASTM C39/C39M-14. Standard test method for compressive strength of cylinderical concrete specimens. The American Society for Testing and Materials, 2014.

ASTM C476-02. Standard specification for grout for masonry. The American Society for Testing and Materials, 2009. 
Colalillo, M. A.; Sheikh, S. A. 2012. Seismic retrofit of shearcritical reinforced concrete beams using CFRP, Construction and Building Materials 32: 99-109. http://dx.doi.org/10.1016/j.conbuildmat.2010.12.065

Concrete Society, Corrosion Prevention Association, Institute of Corrosion (CS). 2009. Repair of concrete structures with reference to BS EN 1504, Issue 69 of Concrete Society technical report.

Cromwell, J. R.; Harries, K. A.; Shahrooz, B. M. 2011. Environmental durability of externally bonded FRP materials intended for repair of concrete structures, Construction and Building Materials 25(5): 2528-2539. http://dx.doi.org/10.1016/j.conbuildmat.2010.11.096

Csuka, B.; Kollár, L. P. 2012. Analysis of FRP confined columns under eccentric loading, Composite Structures 94(3): 1106-1116 http://dx.doi.org/10.1016/j.compstruct.2011.10.012

Ferrier, E.; Michel, L.; Jurkiewiez, B.; Hamelin, P. 2011. Creep behavior of adhesives used for external FRP strengthening of RC structures, Construction and Building Materials 25(2): 461-467.

http://dx.doi.org/10.1016/j.conbuildmat.2010.01.002

FIB. 2001. Externally bonded FRP reinforcement for $R C$ structures, technical report on the design and use of externally bonded fibre reinforced polymer reinforcement (FRP EBR) for reinforced concrete structures, Vol. 14. International Federation for Structural Concrete. Bulletin (fib). 130 p.

FIB. 2006. Retrofitting of concrete structures by externally bonded FRPs with emphasis on seismic applications, Vol. 35. International Federation for Structural Concrete. Bulletin (fib). 217 p.

Gambhir, M. L. 2010. Concrete technology 4E. $4^{\text {th }}$ ed. New Delhi: McGraw-Hill Education, Pvt Limited. 716 p.

Gdoutos, E. E.; Pilakoutas, K.; Rodopoulos, C. A. 2000. Failure analysis of industrial composite materials. New York: McGraw-Hill. 555 p.

Giuseppe, C. 2006. Influence of FRP wrapping techniques on the compressive behavior of concrete prisms, Cement and Concrete Composites 28(5): 497-505. http://dx.doi.org/10.1016/j.cemconcomp.2006.01.002

Gu, D. S.; Wu, Y. F.; Wu, G.; Wu, Z. S. 2012. Plastic hinge analysis of FRP confined circular concrete columns, Construction and Building Materials 27(1): 223-233. http://dx.doi.org/10.1016/j.conbuildmat.2011.07.056

Guoqiang, L. 2006. Experimental study of FRP confined concrete cylinders, Engineering Structures 28(7): 1001-1008. http://dx.doi.org/10.1016/j.engstruct.2005.11.006

Hadi, M. N. S. 2007. Behaviour of FRP strengthened concrete columns under eccentric compression loading, Composite Structures 77(1): 92-96. http://dx.doi.org/10.1016/j.compstruct.2005.06.007

Hag-Elsafi, O.; Alampalli, S.; Kunin, J. 2004. In-service evaluation of a reinforced concrete T-beam bridge FRP strengthening system, Composite Structures 64(2): 179-188. http://dx.doi.org/10.1016/j.compstruct.2003.08.002

IAEE. 1992. Proceedings of the Tenth World Conference on Earthquake Engineering, 19-24 July 1992, Madrid, Spain, International Association for Earthquake Engineering. Brookfield: A. A. Balkema. 5207 p.

İlki, A.; Karadogan, F.; Pala, S.; Yuksel, E. 2009. Seismic risk assessment and retrofitting with special emphasis on existing low-rise structures, Vol. 10. Geotechnical, Geological and Earthquake Engineering. Springer. 495 p.

Jiang, T.; Teng, J. G. 2007. Analysis-oriented stress-strain models for FRP-confined concrete, Engineering Structures 29(11): 2968-2986. http://dx.doi.org/10.1016/j.engstruct.2007.01.010
Jiang, T.; Teng, J. G. 2012. Theoretical model for slender FRP-confined circular RC columns, Construction and Building Materials 32: 66-76. http://dx.doi.org/10.1016/j.conbuildmat.2010.11.109

Komorowski, J. 2011. ICAF 2011 structural integrity, influence of efficiency and green imperatives, in Proceedings of the $26^{\text {th }}$ Symposium of the International Committee on Aeronautical Fatigue, 1-3 June 2011, Montreal, Canada. 973 p.

Lam, C. C.; Cheng, J. J.; Yam, C. H. 2011. Finite element study of cracked steel circular tube repaired by FRP patching, Procedia Engineering 14: 1106-1113. http://dx.doi.org/10.1016/j.proeng.2011.07.139

Lam, L.; Teng, J. G. 2002. Ultimate axial strain of FRP-confined concrete, Advances in Building Technology 1: 789-796. http://dx.doi.org/10.1016/B978-008044100-9/50099-1

Lam, L.; Teng, J. G.; Cheung, C. H.; Xiao, Y. 2006. FRP-confined concrete under axial cyclic compression, Cement and Concrete Composites 28(10): 949-958. http://dx.doi.org/10.1016/j.cemconcomp.2006.07.007

Li, G.; Kidane, S.; Pang, S. S.; Helms, J. E.; Stubblefleld, M. A. 2003. Investigation into FRP repaired RC columns, Composite Structures 62(1): 83-89. http://dx.doi.org/10.1016/S0263-8223(03)00094-1

Maalej, M.; Leong, K. S. 2005. Engineered cementitious composites for effective FRP-strengthening of RC beams, Composites Science and Technology 65(7-8): 1120-1128. http://dx.doi.org/10.1016/j.compscitech.2004.11.007

Manal K, Z. 2011. Investigation of FRP strengthened circular columns under biaxial bending, Engineering Structures 33(5): 1666-1679. http://dx.doi.org/10.1016/j.engstruct.2011.02.003

Matthys, S.; Taerwe, L. 2006. Evaluation of ductility requirements in current design guidelines for FRP strengthening, Cement and Concrete Composites 28(10): 845-856. http://dx.doi.org/10.1016/j.cemconcomp.2006.07.003

Moy, S. S. J. 2001. FRP composites, life extension and strengthening of metallic structures. Londond: Thomas Telford. 64 p.

Naderian, H. R.; Ronagh, H. R.; Azhari, M. 2011. Torsional and flexural buckling of composite FRP columns with cruciform sections considering local instabilities, Composite Structures 93(10): 2575-2586. http://dx.doi.org/10.1016/j.compstruct.2011.04.020

Pan, J.; Leung, C. K. Y. 2007. Debonding along the FRPconcrete interface under combined pulling/peeling effects, Engineering Fracture Mechanics 74(1-2): 132-150. http://dx.doi.org/10.1016/j.engfracmech.2006.01.022

Panjehpour, M.; Farzadnia, N.; Anwar, M. P.; Ali, A. A. A. 2011. FRP sheets contribution in common repair techniques of concrete structures with emphasis on concrete columns, International Journal of Sustainable Construction Engineering \& Technology 2(2): 54-61.

Promis, G.; Ferrier, E. 2012. Performance indices to assess the efficiency of external FRP retrofitting of reinforced concrete short columns for seismic strengthening, Construction and Building Materials 26(1): 32-40. http://dx.doi.org/10.1016/j.conbuildmat.2011.04.067

Realfonzo, R.; Napoli, A. 2011. Concrete confined by FRP systems: confinement efficiency and design strength models, Composites Part B: Engineering 42(4): 736-755. http://dx.doi.org/10.1016/j.compositesb.2011.01.028

Sasher, W. C. 2008. Testing, assessment and FRP strengthening of concrete T-beam bridges in Pennsylvania. West Virginia University. $185 \mathrm{p}$.

Sasmal, S.; Ramanjaneyulu, K.; Novak, B.; Srinivas, V.; Saravana Kumar, K.; Korkowski, C.; Roehm, C.; Lakshmanan, N.; Iyer, N. R. 2011. Seismic retrofitting of nonductile beamcolumn sub-assemblage using FRP wrapping and steel plate jacketing, Construction and Building Materials 25(1): 175 182. http://dx.doi.org/10.1016/j.conbuildmat.2010.06.041 
Taillade, F.; Quiertant, M.; Benzarti, K.; Aubagnac, C. 2011. Shearography and pulsed stimulated infrared thermography applied to a nondestructive evaluation of FRP strengthening systems bonded on concrete structures, Construction and Building Materials 25(2): 568-574. http://dx.doi.org/10.1016/j.conbuildmat.2010.02.019

Teng, J. G. 2002. FRP-strengthened RC structures. John Wiley \& Sons. $266 \mathrm{p}$.
Teng, J. G.; Yu, T.; Wong, Y. L.; Dong, S. L. 2007. Hybrid FRP-concrete-steel tubular columns: concept and behavior, Construction and Building Materials 21(4): 846-854. http://dx.doi.org/10.1016/j.conbuildmat.2006.06.017

Wei, Y. Y.; Wu, Y. F. 2012. Unified stress-strain model of concrete for FRP-confined columns, Construction and Building Materials 26(1): 381-392.

http://dx.doi.org/10.1016/j.conbuildmat.2011.06.037

Mohammad PANJEHPOUR. He is a senior lecturer in Laureate (INTI) International University in the field of Structural Engineering. He is the leader of Center of Advanced Concrete Technology (CACT) in Laureate (INTI) International University. He was a Postdoctoral Research Fellow in University of Malaya. His primary research interests include Strut-and-Tie Model (STM) as well as strengthening and repairing of concrete structures using Fiber Reinforced Polymer (FRP). He has been working on the application of Ultra High Performance Fiber Reinforced Concrete (UHPFRC) for thin structural elements in collaboration with DURA Technology Company.

Nima FARZADNIA. He is a Senior Researcher in University Putra Malaysia. He is a Research Asistantant in Housing Research Center in UPM. His area of interest lies in concrete materials and nanothechnology. He has published articles on the nanothechnology and high performance concrete.

Ramazan DEMIRBOGA. He is a Professor of Civil Engineering in Ataturk University in Turkey. He has joined the Housing Research Center (HRC) in UPM since 2010. His research interests are related to concrete materials. He has published numerous articles in the field of concrete material such as mineral admixture mortar, high strength light weight concrete, virtual cement, expanded perlite aggregate, and thermal conductivity of concrete.

Abang Abdullah Abang ALI. He is a Professor of Civil Engineering in University Putra Malaysia. In 1982, he was appointed as the Dean of Faculty of Engineering in Universiti Putra Malaysia (UPM). He is the director of Housing Research Center (HRC) in UPM. His research focuses on construction materials and industrialized building system. 